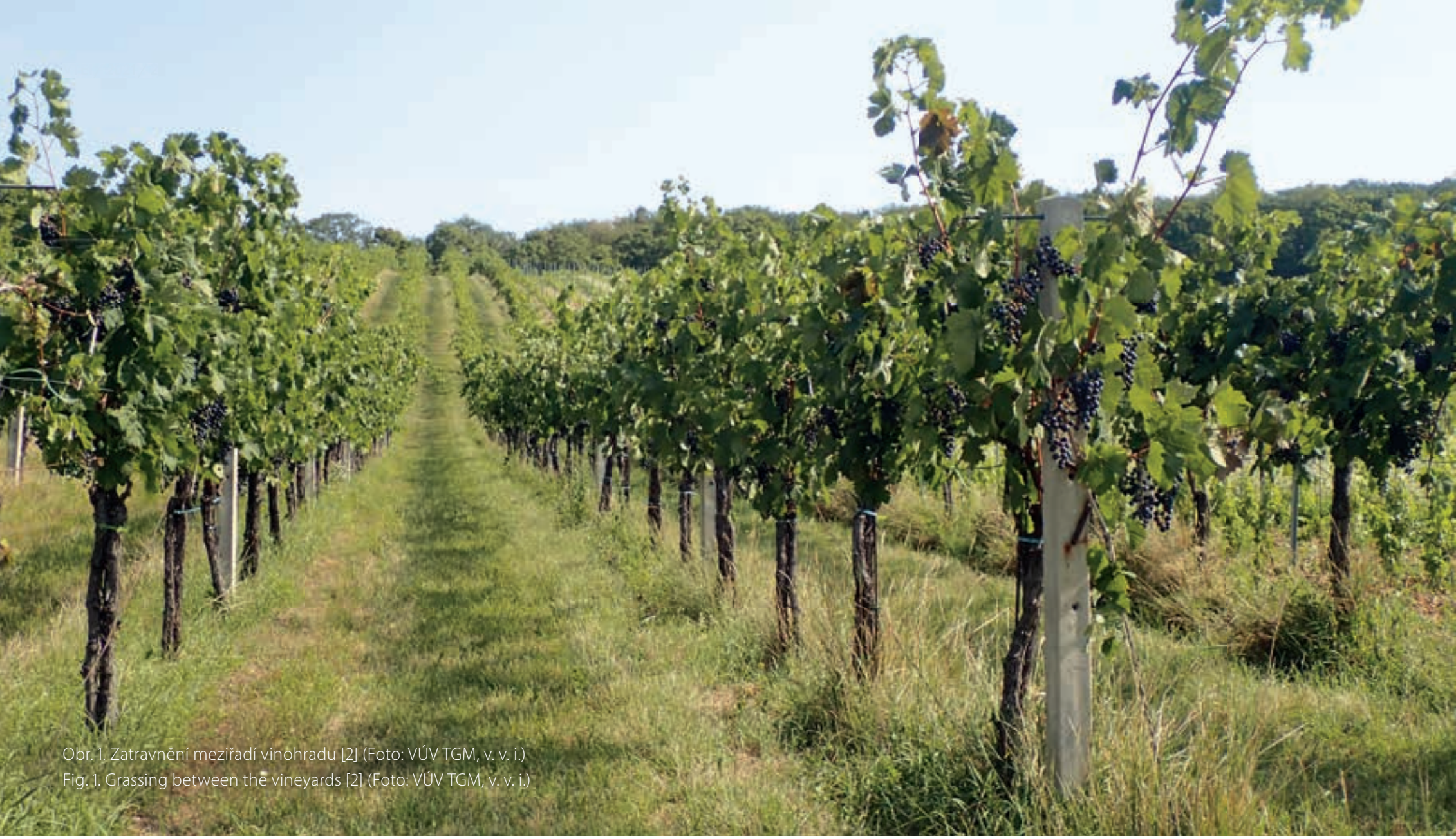

\title{
Adaptace měst a obcí na povodně a sucho
}

\section{PAVEL BALVÍN, VERONIKA TÁBOŘÍKOVÁ, JIŘí PROCHÁZKA, JAN HLOM, LUDMILA ŠNEJDOVÁ}

Klíčová slova: adaptace - povodně - sucho - vnější prstenec města - kategorizace opatření

\section{SOUHRN}

Realizace komplexních adaptačních opatření je v posledních letech významným trendem ve všech velkých městech a obcích Evropy. Potřeba přizpůsobení se změně klimatu, vyznačující se střídáním krátkých a intenzivních povodňových epizod [1] a dlouhých období sucha, donutila predstavitele měst a obcí k přehodnocení dosavadního prístupu k implementaci adaptačních opatření do územně plánovací dokumentace. Adaptační opatření lze rozdělit do několika kategorií. Některá opatření mají pro danou kategorii specifický charakter, jiná se mohou v rámci kategorií vzájemně prolínat. Významným celoevropským trendem ve větších sídelních celcích je tvorba tzv. katalogů opatření. Tyto katalogy vznikají s cílem adaptovat městskou architekturu na změnu klimatu. Převládá v nich jednoznačná snaha vodu z města nejen odvést, ale také ji zadržovat. $V$ mnoha evropských městech je použivání katalogů opatření povinné pro činnost městských architektů [2].

\section{ÚVOD}

Již více než dvacet let jsme vystaveni střídání hydrologických extrémů ve formě povodní a sucha. Povodně se vyskytují jak v podobě fluviální, která postihuje velké oblasti, tak i v podobě pluviální, kdy jsou zasaženy malé sídelní celky povrchovým odtokem z povodí. Nedávná suchá perioda zasáhla celou Českou republiku a měla významný dopad na zemědělství a vodní hospodárství. Současnost a blízká budoucnost vyžaduji tvorbu komplexních opatření, a to jak ve smyslu prevence proti povodním, tak i ve smyslu snížení dopadů sucha. Cílem článku je seznámit čtenáře s komplexním trendem vývoje adaptačních opatření měst a obcí, především v jejich vnějším prstenci. 


\section{ADAPTAČNÍ OPATŘENÍ JAKO OCHRANA A PREVENCE}

Adaptační opatření představují v souvislosti se zmírněním dopadů změny klimatu soubor preventivních a ochranných nástrojů. V současné době jsou preferována taková opatření, jež nejen chrání před účinky povodňových událostí, ale působí i v období sucha. Dưležitým preventivním opatřením je rovněž komunikace s veřejností, protože jedině s její pomocí je možné upozornit na provázanost opatření a prosadit komplexní řešení.

Při realizaci jednotlivých opatření je třeba mít na paměti, že žádné technické ani prírodě blízké opatření neposkytuje z pohledu hydrologického extrému stoprocentní ochranu. Vždy se může vyskytnout větší povodeň nebo sucho, než na které bylo opatření původně navrženo. Míra navržené ochrany je proto vždy úměrná svému účelu, cílové skupině a ekonomickým nákladům spojeným s její realizací.

Adaptační opatření představují soubor technických či přírodě blízkých prvků nebo lidských činností, jež lze realizovat v rámci prevence pred výskytem nepřiznivých dopadů hydrologických extrémů.

Opatření Ize rozdělit do několika základních skupin:

- opatření na zemědělské pưdě

- opatření na lesní pưdě

- opatření na vodních tocích

- opatření v urbanizovaných oblastech

- opatření z hlediska technického zabezpečení budov

- opatření v rámci územního plánování

— opatření ve formě varovných systémů a poskytování informací obyvatelstvu

Tento soubor opatření je ve své komplexnosti vhodný nejen pro malé obce, ale i pro velké sídelní celky, kde se vzájemně prolínají zemědělské, lesní a zastavěné oblasti.

\section{OPATŘENÍ NA ZEMĚDĚLSKÉ PŮDĚ}

Opatření na zemědělské půdě mají za úkol převážně zpomalit a snížit povrchový odtok a snížit erozi půdy. Do určité míry mohou působit i jako určitá prevence proti dopadům sucha tím, že zadržují vodu a zvyšují vlhkost půdy. Česká republika patří vzhledem ke své nedávné historii spojené s družstevním způsobem obhospodařování k zemím s největšími půdními bloky. Důsledkem tohoto způsobu obhospodařování jsou velké délky svahů, urychlení povrchového odtoku a následný vznik zrychlené vodní eroze, případně intenzivní eroze větrná. Spolu se zvýšenou chemizací zemědělství vedou ke snižování kvality půdy, což se kromě snižování produkční schopnosti projevuje i sníženou schopností zadržovat a vsakovat vodu. Výsledným efektem není pouze ochrana vlastní půdy pred erozí, ale zároveň i ochrana zastavěných oblastí pod exponovanými svahy nebo pozemky s nevhodně zvoleným způsobem hospodaření [3].

Významná opatření na zemědělské pưdě se dělí na:

- organizační:

- velikost a tvar pozemku

- zatravnění nebo zalesnění - delimitace půdy

- setba plodin v pásech

— agrotechnická:

— vhodné střídání plodin, užití krycích plodin

- prímá setba, mulčování, kultivace půdy po vrstevnici

— infiltrační a záchytné pásy (obr. 1)

- zachování stávajících luk a pastvin
- technická:

- terasování, meze

— stabilizace drah soustředěného odtoku (obr. 2)

- průlehy, př́kopy, zadržovací hrázky

— vsakovací studny

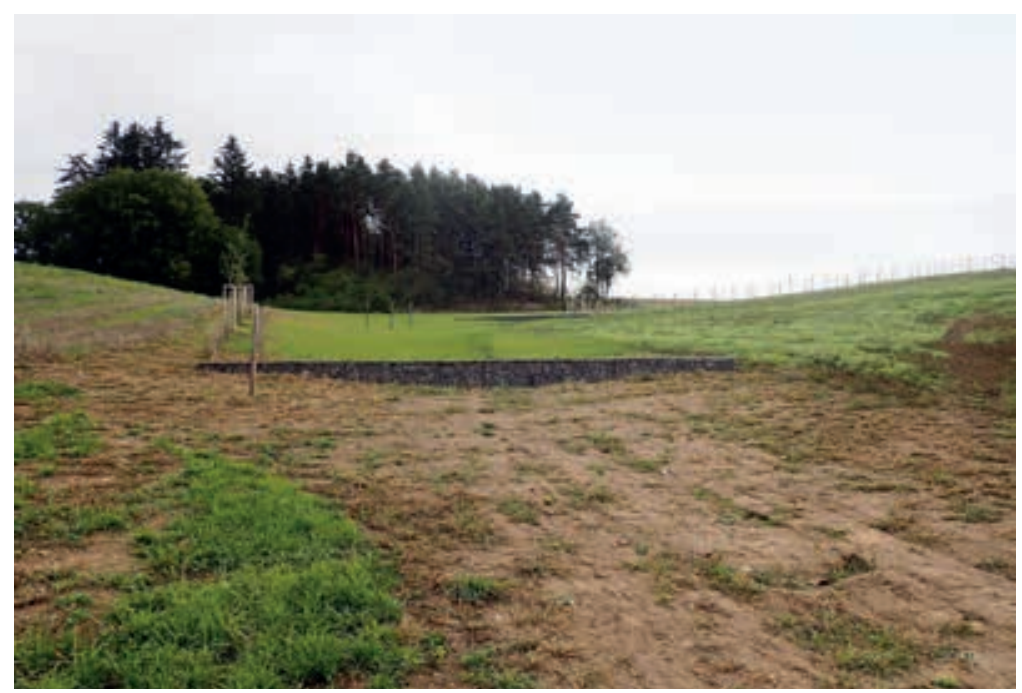

Obr. 2. Gabionová přehrážka v dráze soustředěného povrchového odtoku [2]

Fig. 2. Gabion barrage in the path of concentrated surface runoff [2], (Foto: Vúv TGM, v. v. i.)

\section{OPATŘENÍ NA LESNÍ PŮDĚ}

Zalesněné pozemky významně přispívají ke snížení dopadů hydrologických extrémů v podobě prívalových srážek a sucha. Dokážou částečně zadržet príivalový déšt a rovněž i časově rozložit odtok z území. V rámci zalesněných území Ize realizovat řadu opatření, jež mohou zvýšit účinky zalesněných území z hlediska odtoku v prípadě výskytu prívalových srážek.

U zalesněných pozemků se většinou jedná o tzv. prírodě blízká protipovodňová opatření, která jsou doprovázena i technickými opatřeními. V rámci realizace př́rodě blízkých opatření je důležité si uvědomit omezenost jejich účinků [4], [5].

Mezi významná opatření na lesní půdě patří:

- obnova príirozených smíšených lesů

- pravidelná údržba a zmlazování lesů

— omezení rizika poškození lesní půdy v průběhu těžby

- rychlé zalesnění poškozených pozemků postižených prírodními událostmi

- revitalizace lesních cest a jejich pravidelná údržba

- obnova mokřadů

- podpora prírozené sukcese

- hrazení bystřin a sanace erozních rýh

\section{OPATŘENÍ NA VODNÍCH TOCÍCH}

Vodní toky hrají zásadní roli při bezpečném odvedení povodňových průtoků a zároveň představují důležitý krajinotvorný prvek, jenž může výrazně přispět k zadržení vody $v$ krajině. $\vee$ urbanizovaných oblastech převažuje charakter kanalizovaných toků, jejichž cílem bývalo co nejrychleji odvést povodňový průtok ze zasažené oblasti. Nicméně v posledních letech převažuje silný trend s cílem revitalizovat kanalizované toky i v zastavěných územích, a to takovým způsobem, aby nebyly ohroženy životy, zdraví a majetek obyvatel. Níže uvedená opatření mohou významně přispět k nalezení kompromisu mezi protipovodňovou ochranou a požadavky na ekologický charakter toku. 
Mezi významná adaptační opatření na vodních tocích patři:

— mapování povodňových rizik (mapy rozlivů, mapy hloubek)

- vyhodnocení povodňových škod

- zpomalení odtoku v určitých částech povodí

- obnovení prírozených záplavových území (obr. 3)

- výstavba suchých nádrží

- výstavba malých vodních nádrži

— zajištění dostatečné průtočné kapacity mostů a propustků a jejich ochrana proti ucpání splávím

— pravidelná údržba koryt s cílem zajištění požadované kapacity pro převedení povodňových průtoků

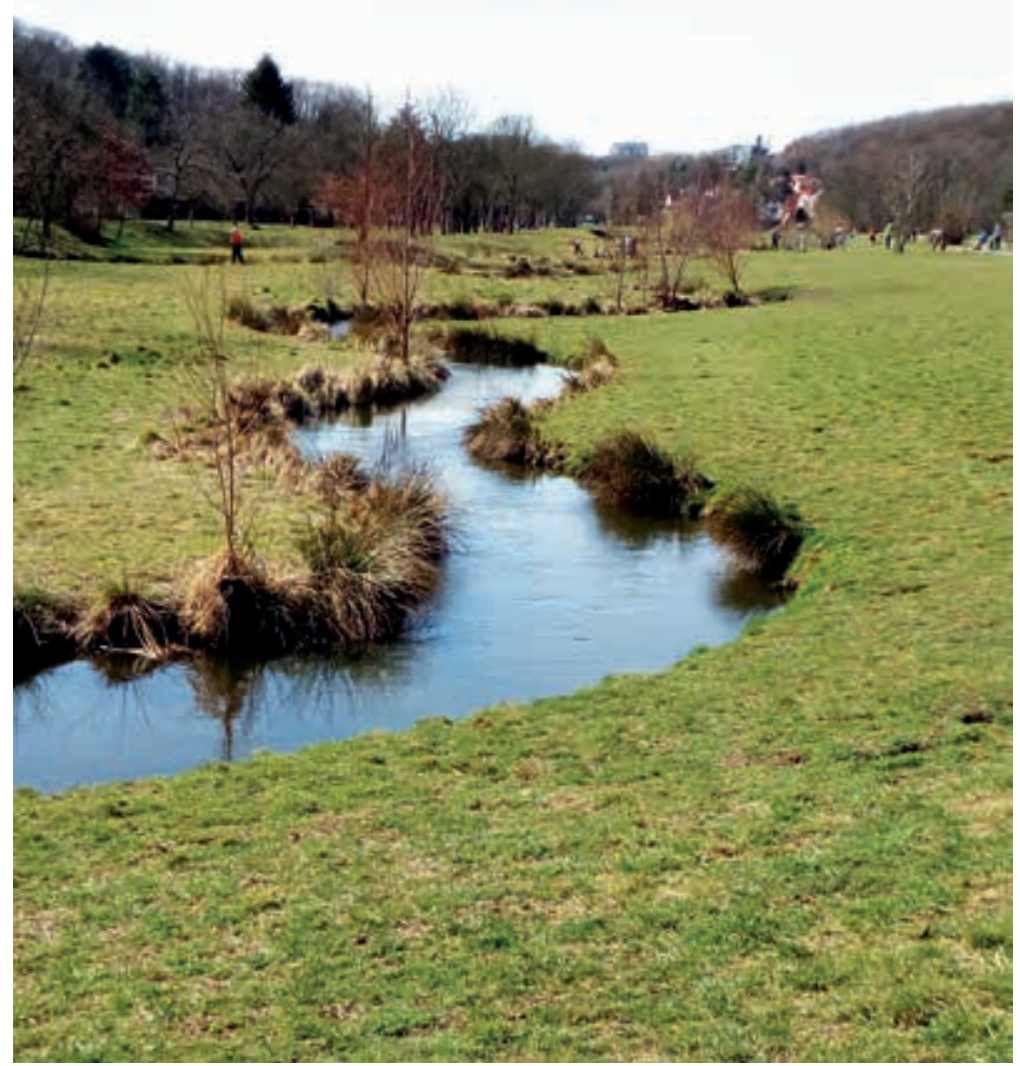

Obr. 3. Revitalizace Rokytky meandrováním se zachováním inundačního území (Foto: Vúv TGM, v. v. i.)

Fig. 3. Revitalization of Rokytka by meandering with preservation of the inundation area (Foto: Vúv TGM, v. v. i.)

\section{OPATŘENÍ V URBANIZOVANÝCH OBLASTECH}

Zastavěná území s velkou hustotou zpevněných ploch představují v současnosti velké riziko z hlediska zhoršení odtokových poměrů. Jejich vlivem dochází ke zkrácení doby dotoku, minimální infiltraci a následně zahlcení odvodňovacích systémů. Důsledkem pak mohou být lokální záplavy a škody na majetku obyvatel i infrastruktuře měst a obcí. Cílem níže uvedených opatření je zpomalit odtok ze zpevněných ploch, zachytit a infiltrovat co největší objem vody. Některá z uvedených opatření snižují dopady v prípadě výskytu přivalových srážek a zároveň umožňují využití zachycené vody v delším časovém horizontu.

— zpomalení a snížení objemu odtoku ze zpevněných ploch (parkovišťt, střech, silnic - propustná dlažba nebo její zdrsnění) a zvýšení vsaku deštových vod

— využití zpevněných ploch coby dočasných retenčních prostor
— dostatečně kapacitní odvodňovací systém deštové kanalizace

— zpětné klapky na odvodňovacích systémech

- dočasné zadržení vody v podzemních nádržích s možností jejich pozdějšího využití

- infiltrace a zpomalení odtoku ze zatravněných ploch (infiltrační pásy, průlehy, príkopy atd.)

- suché nádrže nebo využití terénních depresí k zadržení odtoku (obr. 4)

— v rámci nové výstavby - vhodné prostorové situování nemovitostí s cílem vyhnout se drahám soustředěného/zvýšeného odtoku

- omezení výstavby v rizikových oblastech

- zelené střechy - snižení povrchového odtoku, snížení teploty v horkých dnech

— zelené stěny - obdoba zelených střech, ale ve vertikálním směru

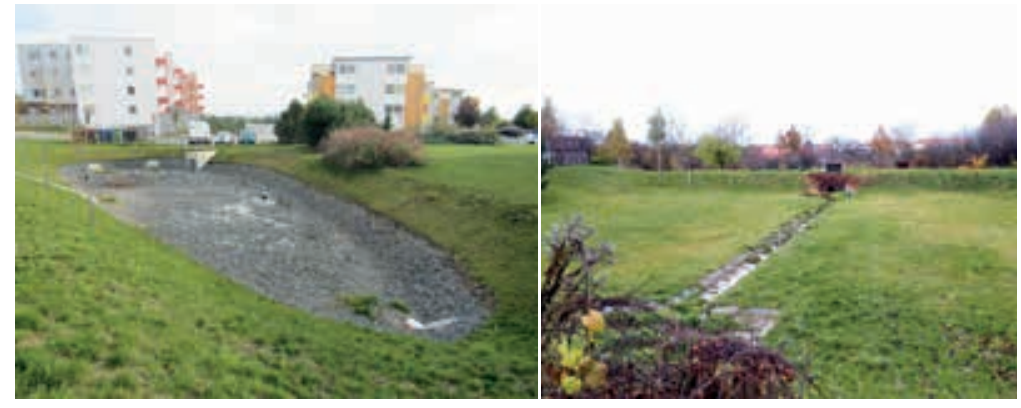

Obr. 4. Suché nádrže pro zachycení odtoku ze zpevněných ploch a následné infiltrace do půdního profilu. Lokalita Kyje (vlevo), Vinoř (vpravo), (Foto: VúV TGM, v. v. i.)

Fig. 4. Polders for capturing runoff from paved areas and subsequent infiltration into the soil profile (Foto: VúV TGM, v. v. i.)

Ne vždy je možné učinit taková opatření, aby dotčená infrastruktura nebyla zasažena soustředěným povrchovým odtokem, a dochází k jejímu dočasnému zaplavení. Z těchto důvodů se nabízí na takto exponovaných objektech provést preventivní technická opatření, jež zajistí co možná nejmenší poškození objektu.

Technické zajištění budov:

- mobilní protipovodňové hrazení

- izolace podzemních částí budov

— zvýšená poloha a ochrana světlíků a vchodů do

sklepů a jejich protipovodňová ochrana

- zvýšená úroveň prízemí (obr. 5)

- utěsnění prostupů potrubí

— technické řešení odtoku vody z budovy v prípadě zatopení

\section{OPATŘENÍ V URBANIZOVANÝCH OBLASTECH V RÁMCI ÚZEMNĚ PLÁNOVACÍ DOKUMENTACE A KONCEPCE ROZVOJE}

Implementace adaptačních opatření již v rámci plánů územního rozvoje měst a obcí představuje jeden z nejdůležitějších preventivních nástrojů pro ochranu životů, zdraví a majetku obyvatelstva.

Vlastní implementace konkrétních adaptačních opatření do územně plánovací dokumentace je závislá na typu dokumentace, jež je v rámci územního rozvoje pořizena.

Územně plánovací dokumentace je dokumentací, která - je-li pořizena představuje závazné koncepční požadavky a podmínky pro rozhodování v území. V podmínkách České republiky existuje několik druhů územně plánovací dokumentace. Podle rozsahu řešeného území ji dělíme do tři druhů zásady územního rozvoje, územní plán a regulační plán -, od nichž se odvijí i měrítko dokumentace, a tedy její výsledná podrobnost. 


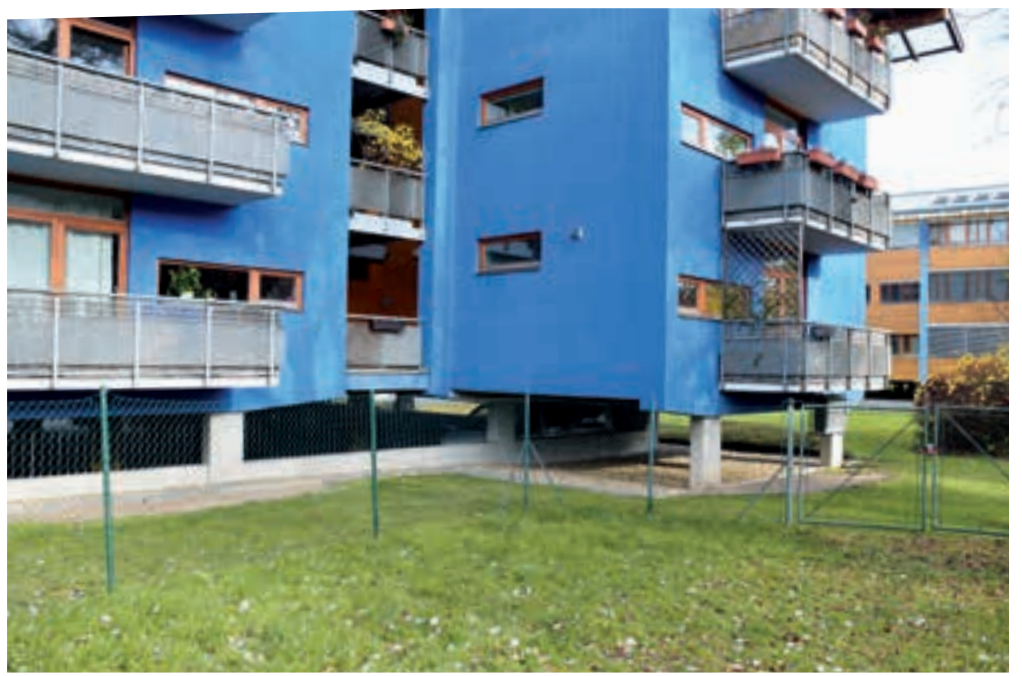

Obr. 5. Navýšené přízemí budov v rámci nové výstavby v záplavovém území Litovického potoka (Foto: VÚV TGM, v. v. i.)

Fig. 5. Elevated ground floor of buildings as part of new construction in the floodplain of Litovický potok (Foto: VúV TGM, v. v. i.)

Při výběru adaptačních opatření, která Ize zahrnout do územně plánovací dokumentace (ÚPD), je uvažováno s rozdělením na dvě kategorie:

— územní plán (ÚP)

— regulační plán (RP; zahrnuje i variantu územního

plánu s prvky regulačního plánu)

Územní plán stanovuje v rozsahu území obce komplexní koncepci jejího rozvoje včetně ochrany, projevující se zejména navrženými plochami, koridory, prípadně trasami a stanovením podmínek pro zpưsoby jejich využití. Regulační plán, vzhledem k jeho zaměření na menší část obce, navrhuje konkrétní umístění a podoby staveb a detailní podmínky.

Hlavním kritériem pro zapracování navrženého adaptačního opatření do těchto dokumentů je podrobnost návrhu. Ta určuje, zda je promítnutelné pouze do územního plánu, nebo zda je možné jeho řešení i podrobnějším způsobem $v$ rámci regulačního plánu.

Vzhledem k tomu, že regulační plán řeší umístění a uspořádání staveb, jejich napojení na infrastrukturu a další podmínky jen do určitého detailu, vyskytují se i taková opatření, která již svou podrobností překračují měřítko regulačního plánu. $V$ takovém prípadě by tato opatření musela být předmětem územního a stavebního řizení. V některých prípadech je také výsledkem začlenění pouze do regulačního plánu, neboť v územním plánu by představovala príliš velkou podrobnost.

Pokud se jedná o podrobnost návrhu adaptačních opatření, v př́padě úP jde o určitý návrh koncepce, jenž se pak následně v RP nechá rozvinout do větší podrobnosti.

Obecná adaptační opatření v rámci koncepce plánování rozvoje měst a obcí:

— nastavení koncepce rozvoje s ohledem na povodňová

rizika včetně povodní z prívalových srážek

— vymezování zastavitelných ploch v územních

plánech s ohledem na povodňové riziko

- uplatňování požadavků plynoucích z existence povodňového rizika v rámci povolovacího procesu

— vymezování ploch vhodných pro vsakování nebo kontrolované odvedení vod v územně plánovací dokumentaci

- eliminace vlivu staveb v oblastech s povodňovým rizikem

— identifikace a mapování rizikových oblastí
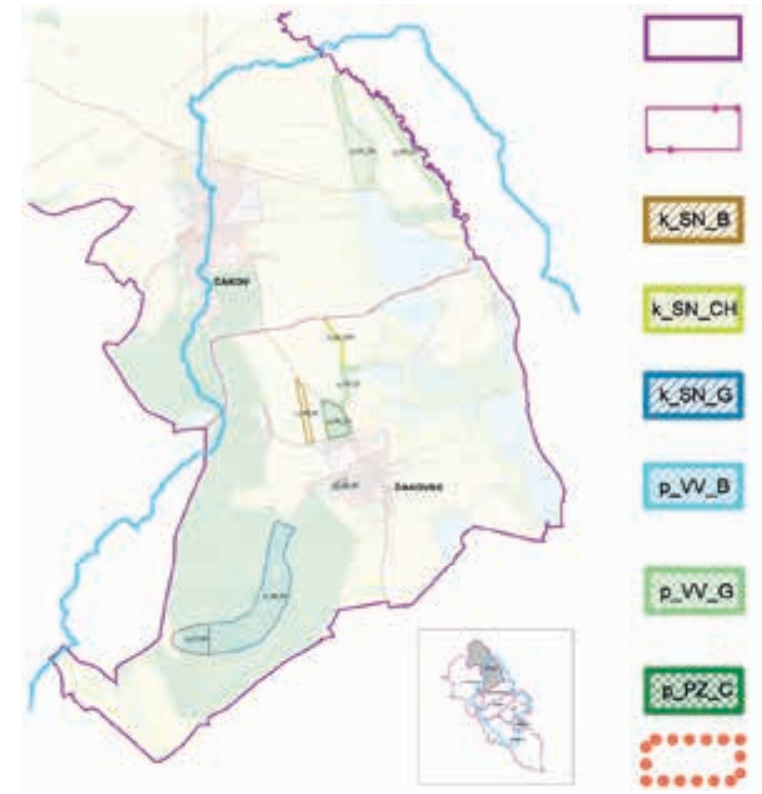

HRANICE SPRAVWHO UZENG OeCE

\section{iecuve.}

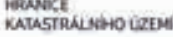

nomiookr suses nelastaveneno üze: net: nomooser susbes MEZASTAVENEHO ÜZEM makbovad ple

\section{NORDORY SUSENE} REZASTAVEVEHO UZZEM sociluas pletralet

procerr voond A VOOOHOSPOOAASXE molis rodoinisiart

Accorr voowe A VOOOHOSPCOAliset igreva vederitoly do prinode sticitho stan

Obr. 6. Príklad implementace opatření do regulačního plánu obce Čakov (Zdroj: VúV TGM, v. v. i.)

Fig. 6. Example of implementation of measures into the regulatory plan of the municipality of Čakov (Source: VÚVTGM, v. v. i.)

— identifikace a implementace vhodných opatření na úrovni obcí i soukromých subjektů

- zahrnutí území ohrožených prívalovými srážkami do územního plánování

- efektivní nakládánís místy určenými pro retenci vody v rámci povodí

\section{OPATŘENÍ VE FORMĚ LOKÁLNÍCH VAROVNÝCH SYSTÉMU゚ A POSKYTOVÁNÍ INFORMACÍ OBYVATELSTVU}

Lokální varovné systémy (LVS) jsou systémy sloužící k varování obyvatelstva před hrozícím nebezpečím. Toto nebezpečí mohou představovat i povodně z prívalových srážek. Systémy pracují na principu včasné výstrahy, kdy hrozící nebezpečí je zachyceno príslušným opatřením (srážkoměr, vodoměrný profil) a tato informace je předána odpovědným osobám či osobě, které ji vyhodnotí a následně provedou nezbytné úkony.

Nejběžnějším prostředkem pro zachycení informací o povodňovém nebezpečí je srážkoměrná stanice nebo prímo v korytě toku vodoměrný profil. Tvorba LVS je nejčastěji ovlivněna těmito parametry:

- geografické a hydrologické charakteristiky zájmového území

- výskyt typů povodní v zájmovém území

- kritická místa v ochraně před povodněm

— existence stávajících hlásných profilů ČHMÚ a podniků Povodí

- blízkost již provozovaných LVS v zájmové lokalitě

— zkušenosti místních obyvatel

Ve vybraných místech jsou situovány on-line měřicí systémy (srážkoměr, hladinoměr), jež zaznamenávají sledované parametry a $v$ případě překročení limitní hodnoty odešlou alarmové informace na přijímací stanoviště. Měřicí technika kromě limitních stavů většinou průběžně měři sledovaný parametr (poloha hladiny), a to v pravidelných časových intervalech. 
ZÁVĚR

Kategorizace a tvorba katalogů [2] adaptačních opatření představuje současný trend řešení adaptace měst a obcí na povodně a sucho. V řadě měst a obcí vznikají studie proveditelnosti s cílem navrhnout opatření pro snížení povodňových rizik a zároveň zadržet co nejvíce vody pro její pozdější využití. Stejně tak v zemědělsky obhospodařované krajině se hledá kompromis mezi realizací prírodě blízkých a technických opatření. V současné době již byla realizována řada výzkumů s cílem posoudit a kvantifikovat účinnost jednotlivých opatření [3], [4], [5]. Kromě studií v pilotních oblastech již existuje i řada webových aplikací a nástrojů zabývajících se problematikou sucha, např. www.suchovkrajině. Zde je možné dohledat katalog opatření, pilotní studie, plán pro zvládání sucha, metodiku a mapové podklady. Z hlediska povodní je možné použít výstupy projektu Strategie ochrany před negativními dopady povodní a erozními jevy prírodě blízkými opatřeními v České republice (www.vodavkrajine.cz).

Zkušenosti z hlediska sucha a povodní lze čerpat i z mezinárodních projektů. Jako príklad Ize uvést projekt Rainman, který byl financován z prostředků programu Interreg Central Europe. Projekt prezentuje výsledky a zkušenosti šesti středoevropských zemí s prístupem ke snížení dopadů povodní z přivalových srážek ve formě katalogu opatření, legislativních podkladů a z pilotních oblastí (www.rainman-toolbox.eu). Významnou součást projektu představuje i soubor opatření realizovatelných již v rámci územně plánovací dokumentace.

Územně plánovací dokumentace představuje významný nástroj pro implementaci jednotlivých opatření ještě před vlastní projektovou prípravou. Ačkoli realizace takovýchto opatření není časově závazná, jasně definuje budoucí využití daného území. Vzhledem k tomu, že je územní plán veřejně projednáván, představuje takto schválená dokumentace formu celospolečenské dohody.

\section{Poděkování}

Článek byl vypracován v rámci projektu „Analýza adaptačnich opatření ke zmírnění dopadů změny klimatu a urbanizace na vodní režim ve vnějši části Prahy" (CZ.071.02 I 0.0 / 0.0 /16_040 / 0000380) financovaného z operačního programu Praha - pól růstu České republiky.

\section{Literatura}

[1] ROŽNOVSKÝ, J., CHUCHMA, F., FIALA, R. a KOHUT, M. Vláhová bilance - ukazatel vody $\checkmark$ krajině. Vodohospodářské technicko-ekonomické informace. 2018, roč. 60, č. 3, s. 12-17. ISSN 0322-8916.

[2] DZURÁKOVÁ, M., ŠTĚPÁNKOVÁ, P. a LEVITUS, V. Katalog přírodě blízkých opatření pro zadržení vody $\vee$ krajině a jeho uplatnění ve webové mapové aplikaci pro veřejnost. Vodohospodáŕskétechnickoekonomické informace. 2018, roč. 60, č. 5, s. 6-11. ISSN 0322-8916.

[3] KRÁSA, J., TEJKL, A. a STAŠEK, J. Určení rozsahu půdy nechráněné vegetací v období přivalových srážek za účelem posouzení erozního rizika. Vodohospodářské technicko-ekonomické informace. 2019, roč. 61, č. 2, s. 39-45. ISSN 0322-8916.

[4] VIZINA, A. STROUHAL, L., DZURÁKOVÁ, M. MORAVEC, V. a MELIŠOVÁ, E. Studie hodnocení účinku prírodě blízkých opatření v povodí Olešné u Pelhřimova pomocí modelů BILAN, HEC-HMS a HYPE. Vodohospodářské technicko-ekonomické informace. 2018, roč. 60, č. 5, s. 12-20. ISSN 0322-8916.

[5] OSIČKOVÁ, K. a UHROVÁ, J. Posouzení efektivity navržených opatření v ploše povodí hydrologickým modelem. Vodohospodárské technicko-ekonomické informace. 2018, roč. 60, č. 3, s. 4-10. ISSN 0322-8916.

\section{Autoři}

Ing. Pavel Balvín ${ }^{1}$

凶pavel.balvin@vuv.cz

ORCID: 0000-0001-7892-7584

\section{Bc. Veronika Táboříková}

凶veronika.taborikova@vuv.cz

ORCID: 0000-0001-5909-4476

Ing. Jiří Procházka, Ph.D.

凶jiri.prochazka@vuv.cz

ORCID: 0000-0002-3444-2347

Ing. Jan Hlom ${ }^{1}$

凶jan.hlom@vuv.cz

ORCID: 0000-0002-1365-3604

Ing. arch. Ludmila Šnejdová

凶snejdova@kraj-jihocesky.cz

'Výzkumný ústav vodohospodářský T. G. Masaryka, v. v. i.

${ }^{2}$ Krajský úřad Jihočeského kraje

Příspěvek prošel lektorským řízením.

DOI: 10.46555/VTEI.2021.01.003

\section{ADAPTATION OF TOWNS AND MUNICIPALITIES TO FLOODS AND DROUGHT \\ BALVIN, P.'; TABORIKOVA, V. .'; PROCHAZKA, J.'; HLOM, J'; SNEJDROVA, L. ${ }^{2}$}

${ }^{1} T$ GM Water Research Institute, p. r. i.

${ }^{2}$ South Bohemia Regional Authority

Keywords: adaptation - floods - drought outer ring of the city - categorization of measures

The implementation of comprehensive adaptation measures has been a significant trend in recent years in all major cities in Europe. The need to adapt to climate change, characterized by alternating short floods (mostly from torrential rainfall) and long periods of drought, has forced cities and municipalities to reconsider the current approach to the implementation of adaptation measures in spatial planning documentation. For this reason, adaptation measures are divided into several categories, where some measures are universal for a given category and others may overlap within categories. A significant pan-European trend in larger settlements is the creation of so-called catalogues of measures. These catalogues are created with the aim of adapting urban architecture to climate change, where we try not only to drain water from the city, but also to retain it in order to improve the living conditions of the population. In many European cities, the use of catalogues of measures is mandatory for the work of urban architects. 